\title{
Velilerin Sınıf Öğretmenlerine Bakış Açılarının İncelenmesi
}

\author{
Özgür Babayiğit \\ Yozgat Bozok Üniversitesi, Eğitim Fakültesi, Yozgat \\ ozgur.babayigit@bozok.edu.tr \\ ORCID ID: https://orcid.org/ 0000-0001-6123-0609
}

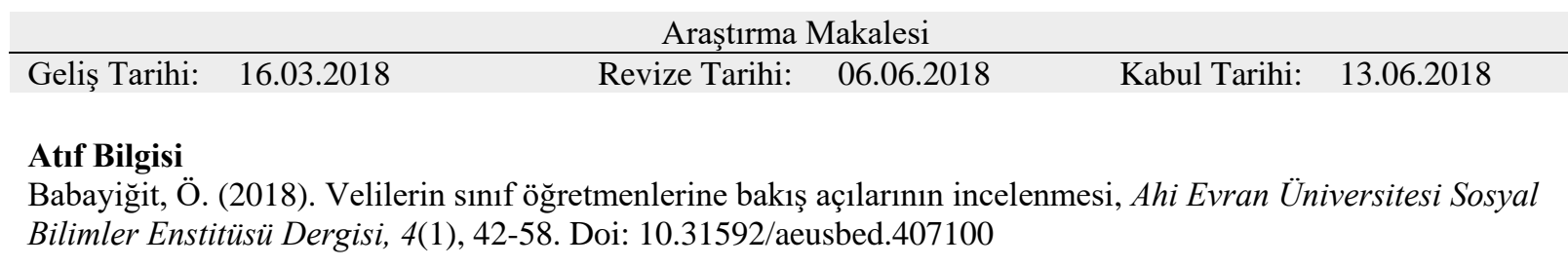

ÖZ

$\mathrm{Bu}$ araştırma değişen toplumumuzda velilerin sınıf öğretmenlerine olan bakış açılarını ortaya koyması açısından önemlidir. $\mathrm{Bu}$ araştırmanın amacı velilerin sınıf öğretmenlerine olan bakış açılarının incelenmesidir. Araştırma nitel araştırma yöntemlerinden olgu bilim (fenomenoloji) yöntemiyle gerçekleştirilmiştir. Katılımcıların belirlemesinde amaçlı örnekleme yöntemlerinden kolay ulaşılabilir durum örneklemesi ve ölçüt örnekleme kullanılmıştır. Veri toplama aracı olarak, araştırmacı tarafından geliştirilen yarı yapılandırılmış görüşme formu kullanılmıştır. Veriler, araştırmacı tarafından hazırlanan yarı yapılandırılmış görüşme formu ile toplanmıştır. Velilerle yapılan görüşmeler ses kayıt cihazına kaydedilmiştir. Görüşmeler bireysel olarak sessiz bir ortamda gerçekleştirilmiştir. 20 veli ile görüşme yapılmıştır. Görüşmeler ortalama 15 dakika sürmüştür. Toplamda 318 dakika görüşme yapılmıştır. Veriler 2017 yılı mart ayında toplanmıştır. Yazılı olan görüşler belirli kodlar, kategoriler ve temalar altında gruplandırılmıştır. Veli görüşleri üzerinde yapılan içerik analizi sonucunda üç adet temaya ulaşılmıştır. Ulaşılan temalar şunlardır: memnuniyet, özveri, saygınlık. Veli görüşleri sonucunda, velilerin sınıf ögretmenlerinden yüzde doksan oranında memnun oldukları belirlenmiştir. Sınıf öğretmenlerinin büyük bir özveri ile çalıştıkları tespit edilmiştir. Saygınlık konusunda ise farklı görüşler mevcuttur. Araştırma sonucunda önerilerde bulunulmuştur.

Anahtar Kelimeler: Veli, sınıf öğretmeni, bakış açısı, inceleme

\section{Investigation the Views of Parents' to Primary School Teachers}

\begin{abstract}
This research is important to reveal the attitudes of the parents to the class teachers in our changing society. This research is the study of the intentions of the intended parents and their teachers. The research was carried out by means of phenomenology from qualitative research methods. In the identification of the participants, easy accessible case sampling and criterion sampling were used for purposeful sampling methods. The semistructured interview form developed by the researcher was used as data collection tool. The data were collected by a semi-structured interview form prepared by the researcher. The interviews recorded on the voice recorder. The interviews were conducted in an individually quiet environment. 20 parents were interviewed. The talks lasted approximately 15 minutes. A total of 318 minutes were interviewed. The data were collected in March, 2017. Written opinions are grouped under certain codes, categories and themes. As a result of the content analysis on the opinions of the parents, three themes were reached. The themes reached are: satisfaction, self-sacrifice, respectability. As a result of the parents' opinions, it was determined that the parents were satisfied with ninety percent of the class teachers. It has been found that class teachers work with great devotion. There are different views on respectability. Suggestions were made as a result of the research.
\end{abstract}

Keywords: Parent, primary school teacher, view, examination

\section{Giriş}

Öğrencinin okul başarısında üç sacayağı bulunmaktadır. Bunlar; öğretmen, öğrenci ve velidir. Gelecekte öğrencinin başarılı olabilmesi için okul döneminde akademik anlamda başarı elde etmesi beklenmektedir. Öğrencinin okulda akademik olarak başarılı olabilmesi, okulun, ailenin ve öğrencinin bütünlük içinde sürekli çalışmasına bağlıdır (Bayrakdar ve Yiğit, 2006). Öğretmen ve ailenin birbirini iletişim kurarak tanıması çocuk, aile, öğretmen üçgeni için güvenli bir bağ oluşturmakta ve çocuğun 
aileye, öğretmene ve okula olumlu bakmasına olanak tanımaktadır (Binicioğlu, 2010). Öğretmen, aile ve öğrenci üçgeninin uyumu ve işbirliği önemli katkılar sağlamaktadır (Aydoğan, 2006). Çocuğun gelişim düzeyleri göz önüne alındığında, ilkokulun ilk üç yılında aileye çok gereksinim duyulduğu ve okulla ailenin bütünlük içinde olması gerektiği ortaya çıkmaktadır (Binicioğlu, 2010). Öğrencinin başarısındaki saç ayaklarından biri olan velilerin, öğretmene ve okula bakış açıları son derece önemlidir. Yapılan bu araştırmanın giriş bölümünde öncelikle öğretmen konusu incelenmiş, ardından veli konusuna değinilmiştir.

Sınıf öğretmenleri, ülkemizde 12 yıl zorunlu eğitimin ilk aşaması olan ilkokullarda görev yapmaktadırlar. İlkokul kelimesi "ilk" ve "okul" kelimelerinin birleşiminden oluşmuştur. İlkokul Fransızca "école primaire" kelimelerinden gelmektedir. Anlamı ise, öğrencilerin zorunlu eğitimdeki ilk aşamadır (Hayes, 2010).

Öğretmenler, öğrencilere neyi bildiklerini, nasıl öğrenebileceklerini gösteren entelektüel liderlerdir (Waid ve McNergney, 2002). Öğretmenler öğrenciler üzerinde güçlü ve kalıcı bir etkiye sahiptir. Öğretmenler öğrencilerin öğrenme biçimini, öğrendiklerini ve ne kadar öğrendiklerini doğrudan etkilemektedirler. Öğrenci başarısı öğretmen etkililiğiyle ilişkilendirilmiştir (MegayNespoli, 2005). Öğretmen asırlardır öğretim sürecinde başroldedir. Bu rol ağırlıklı olarak öğreticilik olarak ön planda iken farklı zamanlarda danışman, mesleki uzman, toplumsal lider, otorite figürü, aile reisi, rehber olarak kendini göstermektedir. Örgün eğitim kurumlarında araç-gereç sağlama, öğretim etkinliklerini uygulama ve değerlendirme gibi işlemleri içermekte olup, bu işlemleri yürütme sorumluluğu öğretmene aittir (Sünbül, 1996). Öğretmenin birçok yönü vardır. Bunlar: müfredat uygulaması, ders planlama, öğrencinin ilerleme durumunu değerlendirmek ve raporları derlemektir. Bunun yanı sıra fedakârlık, merhamet, öğrencilerini sevme gibi sorumlulukları bulunmaktadır (Hayes, 2010). Yeni nesillerin niteliği şüphesiz onu yetiştiren öğretmenlerin niteliği ile özdeştir. "Ektiğini en geç biçen çiftçi öğretmendir" özdeyişi bu gerçeği doğrulamaktadır. Kısaca öğretmenler, insan mimarı, insanın kişiliğini şekillendiren bir sanatkârdır (Çelikten, Şanal ve Yeni, 2005). Öğretmen, okul kavramı içerisinde, bilgiyle buna talepte bulunanlar arasındaki köprüyü oluşturan en önemli ögedir (Mustan, 2002). Öğretmen mesleki açıdan, konuları belli bir gruba öğreten ve davranışlarıyla öğrencilere rol model olan meslek mensubudur. Bu iki önemli görevi öğretmenin bilim adamı ve sanatkâr gibi davranmasını gerektirmektedir. Öğretmenin değerleri, tutumları, deneyimleri, davranışları öğrencilerini, toplumu, kendi mesleki geleceğini ve meslektaşlarını etkilemektedir. Doğal olarak onlardan da etkilenerek mesleki ve kişisel varlığını biçimlendirmektedir (Sünbül, 1996). Öğretmenlik, okul ve sınıf ortamında öğrencilerle iletişimin yanı sıra, veliler ve toplumla da iç içe olan bir meslektir. İlişkilerin niteliği yönünden öğretmen-öğrenci ilişkileri, ilgili yasa ve yönetmeliklerce belirlenmiş resmi nitelikte ilişkilerse de mesleğin doğası gereği bu ilişkiler, duygusal yönü ağır basan ilişkilerdir (Çelikten, Şanal ve Yeni, 2005). Eğitim sisteminin en temel öğesi öğretmendir. İyi eğitimi iyi öğretmenler, nitelikli eğitimi ise nitelikli öğretmenler yapmaktadır. Bunun yanı sıra öğretmenin eğitim-öğretim etkinlikleri ve rolleri giderek artmaktadır. Öğretmenlik, özel uzmanlık mesleği olmanın yanı sıra bir sanattır (Çelikten, Şanal ve Yeni, 2005). Bunun yanı sıra toplum, öğretmenlerden büyük beklentiler içerisindedir (Hayes, 2010). Öğretmenler haftada ortalama 49,3 saat iş yaşamında geçirmektedir. Öğretmenin bu iş yaşamını temel olarak, dersi planlama, öğretim, değerlendirme ve velilerle iletişim oluşturmaktadır (Waid ve McNergney, 2002).

Bir mesleğin statüsü ile o mesleğin maddi getirileri, meslekte çalışanların maaşları, sosyal imkânları, çalışma şartları ile arasında çok yakın bir ilişki bulunmaktadır. Öğretmenlik mesleğinin günümüzde toplumumuzdaki statüsü diğer bazı mesleklerle karşılaştırıldığında çok gerilerde kaldığı görülmektedir (Çelikten, Şanal ve Yeni, 2005). Öğretmenlerin toplumdaki statüsü üç faktörle belirlenmektedir. Bunlar; 1. öğretmenin yetişmesi, 2. ekonomik, 3. atanma koşulları olduğu görülmektedir. Günümüzde öğretmenler ekonomik olarak son derece yetersiz durumdadırlar (Baskan, 2001). Öğretmenlerin statüsünü belirleyen temel unsurlardan biri sosyal ve ekonomik durumlarıdır. Öğretmen maaşlarının yetersizliği öğretmenlik mesleğinin itibarını olumsuz yönde etkilemektedir. Bu durumun ise öğretmenlik mesleğine daha az yetenekli bireylerin gelmesine neden olduğu çeşitli araştırmalarla vurgulanmaktadır (Çelikten, Şanal ve Yeni, 2005). Öğretmenlik tüm toplumlarda profesyonel bir meslek olarak ele alınmaktadır. Türkiye'de öğretmenlik mesleği özellikle son yıllarda 
ciddi statü kaybına uğramıştır. Bunun nedenleri arasında öğretmen yetiştirme sistemindeki eksiklikler, öğretmen maaşlarının yetersizliği vurgulanmaktadır (Baskan, 2001).

Öğretmenin öğretim sürecinde rol ve sorumlulukları şunlardır: öğrenmeyi sağlama, sınıf yönetimi, değerlendirme, güven verme, aile üyeliği, mesleksel ustalık, topluluk liderliği. Başarılı öğretmenin özellikleri ise şunlardır: sıcak, hevesli, heyecanlı, işe yönelik düzenli olma, öğrencilerinden akademik beklentisi olan, öğrencileri teşvik eden, akademik gelişmelerinden sorumluluk payı çıkaran, konusuna hâkim, derste konusu ile ilgili çalışmalara yönelik olan, aktif ve bilgili kişi. Öğretmenin başarısı öğrencinin başarı, ilgi, tutum ve becerisine yansımaktadır (Sünbül, 1996). Bilim ve teknolojideki hızlı değişim ve gelişmeler bağlamında, toplumsal yapı kendini yenilemektedir. $\mathrm{Bu}$ yenileşme sürecinde, değişimden etkilenen bireylerin gelişim sürecine uyum sağlamaları, gelişime katkıda bulunabilmeleri, "davranış değiştirme mühendisi”" olarak nitelendirilen öğretmenlere yeni sorumluluklar yüklemektedir (Aydın, Şahin ve Topal, 2008). Nitelikten yoksun kişilere değer verilmeyen bir çağda bulunulmaktadır. Ekmeğini el emeği ve eşyaya biçim vermekle kazanan işçilerde nitelik aranan bir dünyada, insana biçim vermekle sorumlu öğretmenlerde niteliğe sırt çevrilemez (Kavcar, 1980). Öğrencilerin farklı durumlarda, başkalarına yönelik açık fikirli olmasında, en etkin model olan öğretmenlerin açık fikirli tutumlar göstermesi gerekmektedir (Sünbül, 1996). Son yıllarda ortaya atılan görüşlere göre ekonomik büyüme, sosyal değişme ve demokratikleşmeyi kapsayan kalkınma süreci bir eğitim sorunudur. İnsanı değiştirmeden hiçbir sosyal, ekonomik ve siyasal gelişme, kısacası sağlıklı bir kalkınmayı başarmak mümkün değildir (Aydın, Şahin ve Topal, 2008). Sosyal ve ekonomik kalkınmada öğretmenin liderliği önem taşımaktadır. Öğretmenin bilgi ve görgüye sahip olması beklenmektedir. Öğretmenler yeni görüşlerin öncüsüdür ve gerçeği araştıran kişilerdir (Sünbül, 1996).

Okulda yapılanlar evde veliler tarafından desteklenmedikçe okul eğitiminde başarıya ulaşmak kolay değildir. Aile ve okul iki farklı toplumsal kurumdur. Farklı beklentiler ile şekillenmişlerdir. Bu iki farklı kurumun öğrencilerin eğitimleri konusunda çıkar birliğine girmesi gerekmektedir (Şimşek ve Tanaydın, 2002). Günün yirmi dört saati içerisinde okul saatleri göz önüne alınırsa, çocuk yaşamının 3/4’ünü bu dönemde aile içerisinde geçirdiği gerçeği ortaya çıkmaktadır. Bu durum, öğrencilik yıllarında çocuk-aile etkileşiminin önemini göstermektedir (Çelenk, 2003). Okul yalnızca çocukların eğitiminden sorumlu değildir. Okul aynı zamanda veli gibi önemli bir okul paydaşının eğitilmesinden de sorumludur (Şimşek ve Tanaydın, 2002). Veliler, öğrencilerin tüm gelişim alanlarından öğretmenler kadar sorumludur. Velilerin ve öğretmenlerin iletişim ve işbirliği halinde olmas1, öğrencilerin gelişimleri açısından büyük bir öneme sahiptir.

Öğretmen ve veli konuları ile ilgili olarak yapılan araştırmalar incelendiğinde; Baskan (2001) tarafından yapılan araştırmaya göre; öğretmenlik mesleği, öğretmenin önemi, öğretmen yetiştirme ve öğretmenlerin rolleri hemen tüm toplumlarda güncelliğini koruyan konu ve kavramlardır. Son on yılda, Amerika Birleşik Devletleri başta olmak üzere pek çok gelişmiş ülke, öğretmenliği ve öğretmen yetiştirme sistemini yeniden sorgulamaya başlamış, reform hamlelerine girişmiştir. $\mathrm{Bu}$ gündemin temel gerekçesi, 21. yüzyılda öğretmenliğin giderek artan önem kazanma beklentisidir. Çelenk (2003) tarafından yapılan; öğrencinin okul başarısı üzerinde aile faktörünün oynadığı rolü konu alan çalışmada şu sonuçlara ulaşılmıştır: Eğitim açısından destekleyici bir tutum içinde bulunan ailelerden gelen çocukların okul başarıları daha yüksektir. Aile bakım, şefkat ve korumasının okul başarısının yükselmesinde önemli bir faktör olduğu anlaşılmaktadır. Koruyucu aile yanında kalan çocukların, eğer uygun şefkat ve kurum sağlandığı takdirde başarılarının yüksek olduğu görülmüştür. Okul ile ortak program üzerinde görüş birliği sağlayarak düzenli iletişim içinde bulunan, bu ortak anlayış içinde çocuğuna eğitim desteği sağlayan velilerin çocuklarının okul başarılarının daha yüksek olduğu anlaşılmaktadır. Çelikten, Şanal ve Yeni (2005) tarafından yapılan araştırmaya göre; insanlar, "öğretmen" kavramına pek çok anlam yüklemektedirler. Bazı anlamlar, daha çok, öğretmen rolü oynayan insanların duygusal olmayan, doğrusal betimlemelerini ve onlardan yerine getirmeleri beklenen görevlerin teknik betimlemelerini yansıtmaktadır. Yüklenen diğer anlamlar, kendilerini öğretmen olarak adlandıran insanların ve onların yaptıkları işlerin çok daha canlı, sıcak ve çok boyutlu bir anlayışla ele alınmasına dayanmaktadır. Anlamının zenginliğini ve önemini açığa çıkarmak için, kişinin, "öğretmen" kavramını irdelemesi yeterlidir. Son yıllarda, öğretmen modeli, giderek artan bir 
şekilde reformcular ve basın tarafından, zeki, liberal bir eğitim görmüş, sosyal hayata önem veren bir profesyonel olarak tanımlanmaktadır. Bu öğretmen modeli, bir ya da daha fazla bilim dalına sıkı sıkıya bağlıdır ve öğrenciler için bilginin erişilebilir ve faydalı olması için zekice çalışmaktadır. Bu tip öğretmenin oluşturduğu imaj, ihtiyaçları, yetenekleri veya koşulları ne olursa olsun, bütün öğrencilerin başarılı olmasına yardım eden bir insan portresine uymaktadır. Çok açıktır ki, insanlar, öğretmenlerde içeriği aktarma ve öğrencilere beceri kazandırma yeteneklerinden daha fazlasını aramaktadırlar. Öğretmenler, sözleri ve hareketleri yoluyla, aydınlanmış, çalışkan, erdemli ve eğitimli bir insan olmanın ne anlama geldiğini göstermektedirler. Öğretmenler, toplumun bu izlenimi doğrultusunda hem öğrencileri şekillendirmekte hem de kendileri şekillenmektedir. Kavcar (1980) tarafindan yapılan araştırmaya göre; ülkemizde eğitim-öğretim sorunu, çok boyutlu bir biçimde giderek önemini sürdürmektedir. Bir yandan okul çağına gelen çocuklarla gençler okul ve üniversite kapılarını zorlarken, öte yandan nitelikli insan yetiştirme sorunu kendini göstermektedir. Yetişkinlerin eğitimi ve onların da çağdaş gereklere uyum yapabilmelerini sağlamak da ayrı bir konudur. Bu sorunun bir de planlama, ekonomik, malî ve politik boyutları vardır. Türk eğitiminde asıl sorun nitelik sorunudur. Nitelikten yoksun kişilere değer verilmeyen bir çağda yaşanılmaktadır. Ekmeğini el emeği ve eşyaya biçim vermekle kazanan işçilerde nitelik (kalifiyelik, vasıf) arandığ 1 bir dünyada, insana biçim vermekle yükümlü öğretmenlerde niteliğe sırt çevrilemez. Eğer yetiştirilmesi amaçlanan insanlarda belirli bir düzey, belli yeterlikler aramadan ve bunu gerçekleştirmeden hep "daha çok"un peşine düşülürse, toplumsal ve ulusal gelişme yolunda çok zaman kaybedilmektedir. Mustan (2002), tarafından yapılan araştırmaya göre; yirmi birinci yüzyılın öğretmeninden beklenen ve zorunlu hale gelen rol ve görevler, öğretmen eğitimiyle yakından ilgili kişilerin çok sık işlediği bir konu durumuna gelmiştir. Her alanda olduğu gibi, öğretmenlik mesleğinin de çağın gereklerinin gerisinde kalmaması ve meslekle ilgili anlayış ve yaklaşımların sürekli gelişip yenilenebilmesi, öğretmen yetiştiren programların ve mesleğe hazırlanan bireylerin farklı düşünmelerini ve hareket etmelerini zorunlu kılmaktadır. Öğretmenin rollerindeki değişikliğin kaynaklarının neler olabileceği, öğretmen için bunların ne anlama geldiği ve bu rolleri yerine getirebilecek öğretmenleri yetiştiren kurumların ne gibi tedbirler alabileceği tartışılmaktadır. Sünbül (1996) tarafından yapılan araştırmaya göre; öğretmenler öğrencileri için model rolündedir. Çocukların kendi güdüleri kadar hem yetişkin hem de akranların özellikle öğretmenlerin rolleriyle özdeşlik kurarak tutum ve değer kazanmaktadır. Öğretmen yüzyıllardır öğretim sürecinde başrolü oynamaktadır. Bu roller kimi zaman ağırlıklı bir şekilde öğreticilik olarak ön plana çıkarken bazı zamanlarda danışman, mesleki uzman, toplumsal lider, otorite figürü, aile reisi, rehber olarak kendini göstermektedir. Örgün eğitim kurumlarında hedef alınan davranışlar, program hazırlama, araç-gereç sağlama, öğretim etkinliklerini uygulama ve sonucu değerlendirme gibi işlemleri içermekte olup, bu işlemlere yürütme sorumluluğu öğretmene aittir. Bununla birlikle öğretmenler informal olarak değişik rolleri gerçekleştirmektedir. Wall ve Hall (2016) tarafından yapılan çalışma, İngiltere'deki öğretmenler ile okullardan ve ileri eğitim yüksekokullarından yapılan uzun süreli bir işbirliği projesi sırasında toplanan verilere dayanmaktadır. Proje, pedagoji, çevre ve öğrencilerin eğilimlerinin yaratıcı kombinasyonlarını sorgulayarak, metabilişsel farkındalığın nasıl geliştirilebileceğine odaklanarak, öğretmen-araştırmacılarla ortaklaşa "öğrenmeyi öğrenmek"i araştırmıştır. Makale, proje öğretmenlerinin meta bilişsel şeyleri farklılaştırmaya çalıştığına dair inancın kuramsal temellerini ortaya koyma çabasıdır. Proje genelinde ortaklaşa üretilen fikirlere dayanan, pragmatik bir üst biliş geliştirme modeli sunulmaktadır. Öğretmenlerin öğrencilerin meta bilişini geliştirmek için kullandıkları pedagojiler ile öğretmenlerin kendi öğrenme ve üst bilişsel bilgi ve becerikliliği arasında anlamlı bir ilişki olduğu ortaya konulmuştur. Genç (2005) tarafından yapılan araştırmada öğretmen-veli görüşmelerinin sağlkklı bir şekilde gerçekleştiği, velilerin öncelikle çocukları derste başarısız olduğunda, başarılı olduğunda, sosyal ve psikolojik problemleri olduğunda öğretmenlerle görüştükleri; öğretmenlerin de velileri çocuklarının ders başarısında bir problem (başarısız) olduğunda, disiplin problemi olduğunda, sosyal ve psikolojik problemi olduğunda görüşmeye davet ettikleri ortaya çıkmıştır.

Eğitim sistemi içerisinde önemli bir yeri bulunan velilerin, ilkokul öğretmenleri hakkındaki düşüncelerinin tespit edilmesi, toplumdaki ve eğitim sistemindeki değişimin daha iyi anlaşılması açısından önemlidir. Velilerin sınıf öğretmenleri hakkındaki görüşleri, toplumun sınıf öğretmenlerine bakış açısı konusunda bizlere fikir vermektedir. Ulaşılan sonuçlar kapsamında, öncelikle eğitim sistemimizi planlayan hükümetlere, Millî Eğitim Bakanlığına önemli ipuçları vermesi açısından 
önemlidir. Bunun yanı sıra, özelde sınıf öğretmenlerinin genelde ise tüm öğretmenlerin velilerin kendileri hakkında neler düşündüklerini belirlemesi açısından önemlidir. Velilerin öğretmenlerin hangi tutum ve davranışlarını beğendikleri, eğer varsa beğenmedikleri davranışlarının tespit edilmesi açısından alan yazına katkı sağlayacağı düşünülmektedir.

\section{Araştırma Modeli}

\section{Yöntem}

Araştırma nitel araştırma yöntemlerinden olgu bilim (fenomenoloji) yöntemiyle gerçekleştirilmiştir. Olgu bilim deseni farkında olduğumuz ancak derinlemesine ve ayrıntılı bir anlayışa sahip olmadığımız olgulara odaklanmaktadır. Bize tümüyle yabancı olmayan aynı zamanda tam anlamını kavrayamadığımız olguları araştırmayı amaçlayan çalışmalar için fenomenoloji uygun bir araştırmadır (Yıldırım ve Şimşek, 2006). Olgu bilim insanların fenomenleri nasıl tecrübe ettiklerinin metodolojik, özenli ve derinlemesine bir şekilde resmedilmesi ve betimlenmesidir (Patton, 2014; Gliner, Morgan ve Leech, 2015). Fenomenoloji, bir fenomenin bireylerin ya da belli bir gurubun deneyimleri açısından tanımlanmasıdır (Christensen, Johnson ve Turner, 2015).

\section{Katılımcilar}

Katılımcıların belirlemesinde amaçlı örnekleme yöntemlerinden kolay ulaşılabilir durum örneklemesi ve ölçüt örnekleme kullanılmıştır. Kolay ulaş1labilir durum örnekleme yöntemi araştırmaya hız ve pratiklik kazandırır (Yıldırım ve Şimşek, 2006; Patton, 2014). Ayrıca ölçüt örnekleme yöntemi kullanılmıştır. Ölçüt örnekleme önceden belirlenmiş bazı önem ölçütlerini karşılayan tüm durumları çalışma ve gözden geçirmektir (Patton, 2014). Burada sözü edilen ölçüt veya ölçütler araştırmacı tarafından oluşturulabilir ya da önceden hazırlanmış bir ölçüt listesi kullanılabilir (Yıldırım ve Şimşek, 2006). Ölçüt olarak, çocuğu ilkokula giden veliler belirlenmiştir. Görüşme yapılan verilere ait demografik veriler Tablo 1'de belirtilmiştir.

Tablo 1

Görüşme Yapılan Velilerin Demografik Özellikleri

\begin{tabular}{cllll}
\hline Sıra no & Cinsiyet & Öğrenim Durumu & Meslek & Yaş \\
\hline 1 & Erkek & Üniversite & Memur & 52 \\
2 & Kadın & Lise & Hizmetli & 35 \\
3 & Erkek & Lise & Hizmetli & 47 \\
4 & Erkek & Lise & Güvenlik görevlisi & 36 \\
5 & Erkek & Üniversite & Öğretim üyesi & 38 \\
6 & Erkek & Üniversite & Öğretim üyesi & 50 \\
7 & Kadın & Lise & Memur & 46 \\
8 & Kadın & Üniversite & Öğretmen & 36 \\
9 & Erkek & Üniversite & Okul müdürü & 37 \\
10 & Erkek & Üniversite & Araştırma görevlisi & 35 \\
11 & Kadın & Lise & Ev hanımı & 37 \\
12 & Kadın & Üniversite & İşi & 33 \\
13 & Kadın & Üniversite & Öğretmen & 37 \\
14 & Kadın & Lise & Ev hanımı & 35 \\
15 & Erkek & Lise & Şoför & 34 \\
16 & Erkek & Üniversite & Memur & 36 \\
17 & Kadın & Ortaokul & Serbest meslek & 33 \\
18 & Kadın & İlkokul & Ev hanımı & 37 \\
19 & Kadın & Lise & Memur & 32 \\
20 & Kadın & Üniversite & Ev hanımı & 40 \\
\hline
\end{tabular}

Tablo 1. incelendiğinde, görüşme yapılan velilerin 9'unun erkek, 11'inin kadın olduğu görülmektedir. Velilerin öğrenim durumları ilkokuldan üniversiteye kadar değişmektedir. Velilerin 
çeşitli mesleklere sahip olduğu görülmektedir. Velilerin yaşları ise 32 ile 52 yaş aralığında değişmektedir.

\section{Veri Toplama Aracı}

Veri toplama aracı olarak, araştırmacı tarafından geliștirilen yarı yapılandırılmış görüşme formu kullanılmıştır. Yarı yapılandırılmış görüşme formu yaklaşımı görüşme sırasında irdelenecek bir sorular veya konular listesini kapsamaktadır (Yıldırım ve Şimşek, 2006). Yarı yapılandırılmış görüşme formatı konuşma süresince farklı sorularla konunun açılmasına ve konu hakkında yeni fikirlere ulaşılmasına yardım etmektedir (Merriam, 2013). Yarı yapılandırılmış görüşme formu, sözlü ankettir (Fraenkel, Wallen ve Hyun, 2011). Yarı yapılandırılmış görüşme formunu oluşturmak amacıyla, ilk olarak konu ile ilgili yapılan araştırmalar (Aydın, Şahin ve Topal, 2008; Azar, 2011; Baskan, 2001; Çelenk, 2003; Çelikten, Şanal ve Yeni, 2005; Genç, 2005; Kavcar, 1980; Megay-Nespoli, 2005; Mustan, 2002; Paredes, 2014; Shein ve Chiou, 2011; Sünbül, 1996; Şimşek ve Tanaydın, 2002; Wall ve Hall, 2016) incelenmiştir. Literatür incelenmesinin ardından oluşturulan yarı yapılandırılmış görüşme formu, nitel araştırma yöntemleri konusunda uzman bir öğretim üyesine, sınıf öğretmenliği alanında uzman bir öğretim üyesine ve son olarak bir sınıf öğretmeninin görüşüne sunulmuştur. Uzman görüşleri sonrasında, yarı yapılandırılmış görüşme formunda çeşitli düzeltme, ekleme ve çıkarmalar yapılmıştır. Yapılan eklemeler özellikle görüşme sorusunun derinlemesine açıklanmasını sağlamak amacıyla sorulan yan sorular olmuştur. Hazırlanan yarı yapılandırılmış görüşme formu pilot olarak bir veliye uygulanmıştır. Pilot uygulamanın ardından yarı yapılandırılmış görüşme formuna son şekli verilmiştir. Yarı yapılandırılmış görüşme formu iki bölümden oluşmaktadır. İlk bölümde velilerin demografik özelliklerini belirlemeye yönelik sorular sorulmuştur. İkinci bölümde ise velilerin sınıf öğretmenleri hakkındaki görüşleri sorulmuştur. Araştırmacı tarafından hazırlanan yarı yapılandırılmış görüşme formu ek-1'de sunulmaktadır.

\section{Verilerin Toplanması}

Veriler, araştırmacı tarafından hazırlanan yarı yapılandırılmış görüşme formu ile toplanmıştır. Olgu bilim araştırmalarında başlıca veri toplama aracı görüşmedir (Christensen, Johnson ve Turner, 2015; Gliner, Morgan ve Leech, 2015; Yıldırım ve Şimşek, 2006). Yarı yapılandırılmış görüşme formunda yer alan sorular görüşme esnasında velilere sorulmuştur. Velilerle yapılan görüşmeler ses kayıt cihazına kaydedilmiştir. Görüşmeler, araştırmacının odasında gerçekleştirilmiştir. Görüşmeler ortalama 15 dakika sürmüştür. Toplamda 318 dakika görüşme yapılmıştır. Veriler 2017 yılı mart ayında toplanmıştır.

\section{Verilerin Analizi}

Olgu bilim araştırmalarında veri analizi, yaşantıları ve anlamları ortaya çıkarmaya yöneliktir (Yıldırım ve Şimşek, 2006). Verilerin çözümlenmesinde içerik analizi kullanılmıştır. İçerik analizinde veriler kodlandıktan sonra, veriler içinde tema ve örüntüler aramak için analitik tekniklere başvurulmaktadır (Glesne, 2012). Ses kayıt cihazına kaydedilen görüşmeler, araştırmacı tarafından bilgisayar ortamında yazıya geçirilmiştir. Yazılı olan görüşler okunduktan sonra, belirli kodlar, kategoriler ve temalar altında gruplandırılmıştır (Creswell, 2012). Verilerin içerik analizi sürecinde, araştırmacı tarafından ve nitel araştırma yöntemleri konusunda uzman bir öğretim üyesi tarafından kodlamalar yapılmıştır. Görüşme verilerinin analizinin güvenirliği için Miles ve Huberman (2015, s. 64) tarafından geliştirilen güvenirlik formülü [Güvenirlik=Görüş birliği sayısı / (Toplam görüş birliği + Görüş ayrılığg sayısı)] kullanılmıştır. Güvenirlik formülü sonucunda, güvenirlik=.88 bulunmuştur. $\mathrm{Bu}$ durum yapılan kodlamaların güvenilir olduğunu göstermektedir. Veriler belirli temalar altında toplanarak, okuyucunun kolayca anlayabileceği bir şekilde sunulmuştur. 


\section{Bulgular}

Temalara ulaşı1ırken öncelikle kodlamalar yapılmıştır. Yapılan kodlamalardan kategorilere ulaşılmıştır. Kategorilerden ise üç adet temaya erişilmiştir. Ulaşılan kodlar, kategoriler ve temalar Tablo 2'de sunulmaktadir.

Tablo 2

Ulaşılan Kodlar, Kategoriler ve Temalar

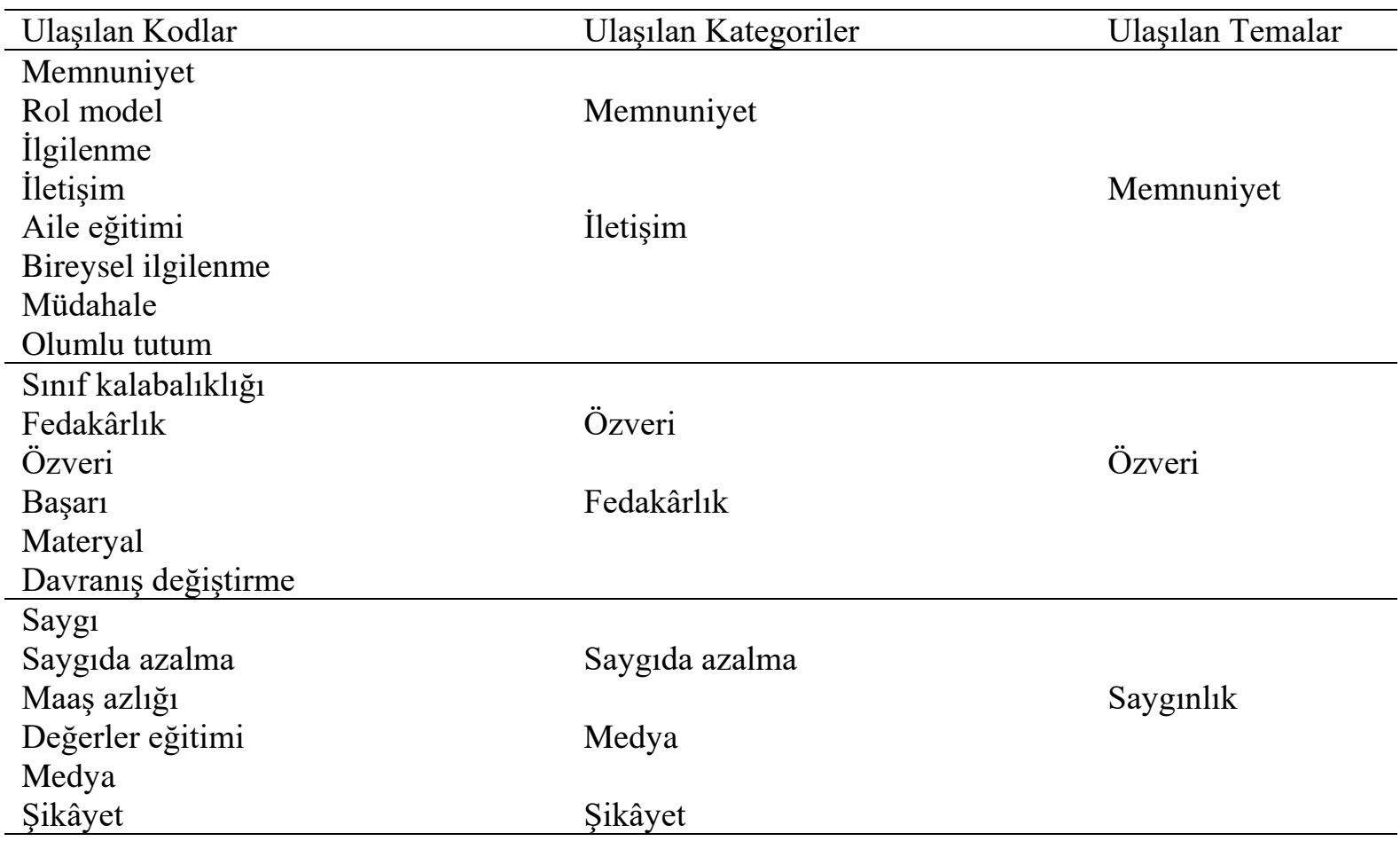

Tablo 2 incelendiğinde, veli görüşleri sonucunda ulaşılan kodlar, kategoriler ve temalar görülmektedir. Veli görüşleri üzerinde yapılan içerik analizi sonucunda üç adet temaya ulaşılmıştır. $\mathrm{Bu}$ temalar Şekil 1'de belirtilmiştir.

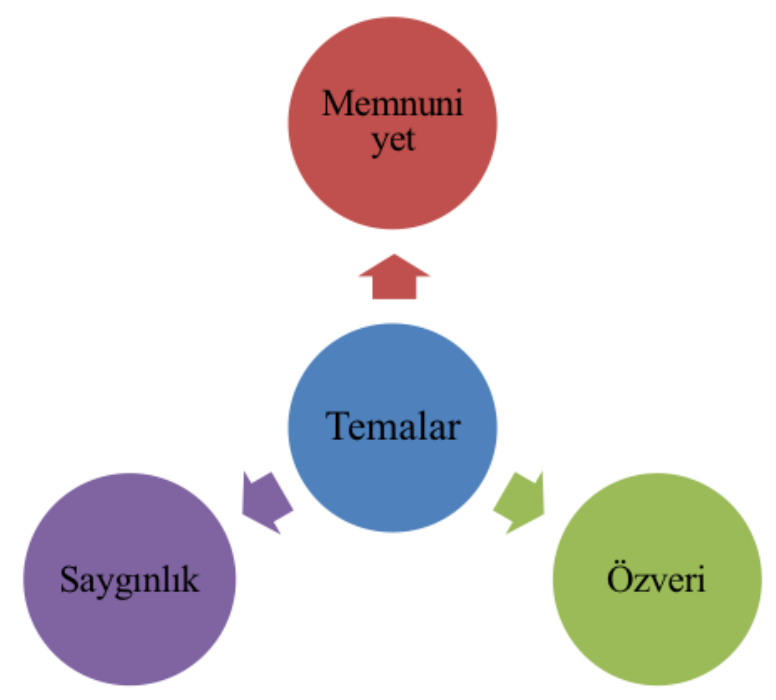

Şekil 1. Temalar

Şekil 1 incelendiğinde, ulaşılan temalar şunlardır: memnuniyet, özveri, saygınlık. Bulgular, ulaşılan bu temalara göre açıklanmıştır. Öncelikle ulaşılan tema memnuniyet temasıdır. Memnuniyet 
temasında velilerin sınıf öğretmenlerinden memnun oldukları anlaşılmaktadır. İkinci olarak ulaşılan tema özveri temasıdır. Veliler sınıf öğretmenlerinin özverili bir şekilde çalıştıklarını belirtmektedirler. Üçüncü ve son olarak ulaşılan tema saygınlık temasıdır. Veliler ilkokul öğretmenlerini saygın ve önemli kişiler olarak görmektedirler. Belirtilen bu temalar aşağıda alt başlıklar altında detaylı olarak incelenmiştir.

\section{Tema: Memnuniyet}

Veli görüşleri sonucunda ulaşılan ilk tema memnuniyet temasıdır. Görüşme yapılan yirmi veliden on sekiz kişi sınıf öğretmenlerinden memnun olduklarını belirtmişlerdir. Ancak iki veli sınıf öğretmeninden memnun olmadıklarını dile getirmiştir. Memnuniyet teması ile ilgili olarak, makalede görüşlerin fazla yer kaplamaması için, velilerin tüm görüşleri burada paylaşılmamıştır. Örnek olarak birkaç veli şunları dile getirmişlerdir:

"Illkokul ögretmeninden gayet memnunum. İnsanlık konusunda çok iyi. Davranışlarla ögrrenciye örnek oluyor. Allah razı olsun ilkokul öğretmeninden." (Veli 4, erkek)

"Mezun olanlardan ilkokul öğretmenlerini araştırdlk. Bu ilkokul öğretmeni iyidir dediler. O ilkokul ögrretmenine yazdirdık. Öğrencilerle ve velilerle ilgileniyor. Whatsapp'tan sürekli iletişime geçiyor. Ödevleri, etkinlikleri için sürekli aileye bilgi veriyor. Insanlı̆̆ ve davranışları çok iyi. Adam gayet iyi. Velilerle falan bir sıkıntı yaşadı̆̆ını hiç duymadım. Geçenlerde bir matematik konusunu, ögretmen velilere anlatmış. Okul çıkışı velilere matematik anlatmış. Her hafta çocuklara kitap okutuyor. Ondan da sinav yapıyor." (Veli 7, kadın)

"İlkokul ögretmeninden memnunum. Ŏglumu kaybetmediği için. Ŏglumla bireysel ilgilenmekte. Ŏglumda dikkat eksikliği olduğunu kendisi tespit etti. Ona göre de program oluşturduk. Öğretmen, kadın velilerden çok çekiyor. Kadın veliler öğretmene çok müdahale ediyorlar. 23 Nisan, 19 Mayıs etkinliklerinde öğretmene çok müdahale ediyorlar. Kermeslerde de öyle. Velileri kırmadan, öğrenciyi çalıştırın diyor. Bazen ögrenciye baskı yapmamızı istiyor çalışma konusunda. Öğretmenimden çok memnunuz. Öğretmenimizi özel okullar istiyor fakat gitmiyor. Öğretmenimiz eğitim kalitesinin artmasindan yana. Programlar haricinde kendine özgü bir programla çalışlyor.” (Veli 5, erkek)

"Sınıf öğretmenimizden memnunum. Ödev konusundaki yaklaşımını beğenmiyorum. Velilerle iletişimi çok güzel. WhatssApp grubu kurdu. Bu sayede iletişime geçiyoruz." (Veli 11, kadın)

"Illkokul öğretmenimiz iyi. Şöyle diyeyim açıkçası. Herhangi bir problemim yok. Bize karşı olumsuz bir durumu yok. Evde eğitim veriyoruz çocuğumuza. Öğretmen yeni başladı görevine. Sınıf biraz kalabalık. 31 kişi." (Veli 15, erkek)

"İlkokul ögretmenlerimizden genel olarak memnunum. Küçük çocuğun öğretmeni emeklisi gelmişs değerli birisi. Bize karşı tutumu çok iyi. Çocuklarla ilgileri ve alakaları çok iyi. Büyük çocuğun ögretmeni çok iyi değil. Ben dersi anlatır geçerim diyor. Çocuğun anlamadığına bakmıyor." (Veli 9, erkek)

\section{Tema: Özveri}

Ulaşılan ikinci tema özveri temasıdır. Özveri temasında, velilerin sınıf öğretmenlerinin özverili çalışmaları ile ilgili görüşleri belirtilmiştir. Özveri teması ile ilgili olarak, makalede görüşlerin fazla yer kaplamaması için, velilerin tüm görüşleri burada paylaşı1mamıştır. Örnek olarak birkaç veli şunları dile getirmişlerdir 
"Iilkokul ögrretmenimden memnunum. Özel okula gidiyor çocuk. Canı çıkıyor zavallı ögretmenin. Öğretmenin biz velilere karşı tutumundan memnunum. Çocukla ilgili bir şey olduğunda bizi arıyor. Çok ilgili. Çocuğumun ödev yapmak zoruna gidiyor." (Veli 2, kadın)

"Eğitim camiasında en başarıll aşama ilkokul. Illkokulda özel okul düşünmedik. İlkokulda öğretmen çoğu şeyi başarıyor. Illkokullarda genel sıkıntı, bayan öğretmen olursa doğum yapması. Küçük yerlerde sık sık ögretmen değişikliği oluyor. İlkokulda sık öğretmen değişimi çocukların moralini bozuyor. Büyük çocuğum öğretmeni kanserdi. Değişti.” (Veli 20, kadın)

"2 ilkokul ögrretmeni değiştirdik. 1-3. Sinfflardaki ilkokul öğretmeninden memnundum. Sürekli soru çözümü, test çözümü yaptırıyordu. Çocukların resimlerini, isimlerini kullantyordu test hazırlarken. Illgili ve alakalıydı. Bizlere karşı tutumu iyiydi. Görüş̧melerde bizimle ilgilenirdi. Öğretmen rahatsızlanınca, çocuğu başka okula aldık. Kanserdi öğretmenimiz. Diğer öğretmen dersten ziyade sosyal yöne ă̆ırlık veriyordu. Öğrencilerin iyi bir insan olması için çaballyor. Not ikinci planda. Eski televizyonun içini boşaltmış. Çocuklar her gün televizyonun arkasına geçip haber okuyor. Öğrencilerin özgüvenleri gelişsin diye." (Veli 6, erkek)

"Biz birinci sınıfta iki ögretmen değiştirdik. Özel okula gönderiyorum. Birinci ögretmen emekli öğretmendi. Şimdiki öğretmen genç. 28 yaşında. Alperen'e söz dinletiyor. Bizim için önemli olan o. Bize karşı tutumundan memnunum. Öğretmen bize de emrediyor. Şunu yap, bunu yap şeklinde. Niye yapmadınız diye hesap soruyor. Dirayetli öğretmen. Oğlumu adam etti. Okulda gülen yüz falan yapıyor. Öğrenciyi motive ediyor." (Veli 17, kadın)

\section{Tema: Saygınlık}

Ulaşılan son tema ise saygınlık temasıdır. Saygınlık temasında velilerin sınıf öğretmenliğinin saygınlığ 1 konusundaki görüşleri belirtilmiştir. Bir veli kendi sınıf öğretmeninin nerde görse elini öptüğünü belirtmiştir. Saygınlık teması ile ilgili olarak, makalede görüşlerin fazla yer kaplamaması için, velilerin tüm görüşleri burada paylaşılmamıştır. Örnek olarak birkaç veli şunları dile getirmişlerdir:

"Ben daha ilkokul öğretmenimin elini öperim. Nerde görsem. Çünkü benim üzerimde hem insani hem ögretmenlik konusunda büyük bir etki bıraktı. Hem okul birincisiydim hem sinıf birincisiydim onun zamanında. Sevdiğim bir insandı. Ders anlatımı çok güzeldi.” (Veli 1, erkek)

"İlkokul ögretmenlerinin eski etkinliği kalmadl. Toplumdaki eski önemi kalmadl. Çocuklarla ilgili bir iş olduğu için toplumda kabul görmeye devam ediyor. Maaşla ve kalabalıkla ilgili sayılarının çokluğu ve maaşlarının azlı̆̆ toplumdaki saygınlıklarını bitirdi." (Veli 3, erkek)

"IIlkokul ögretmenlerinde her şeyi ben bilirim havası var. İlkokulda alışıyorlar galiba buna. Arkadaşlarımda da var. İlkokul öğretmeni. Alışkanlık galiba. İlkokul öğretmenlerinin maaşları bence düşük. Ek dersle 3500 TL. Tek maaşla çalışan biri için düşük. Ev kirası olmuş 1000 lira. Öğretmen ilçede çalışıyorsa toplum açısından değerli. Büyük şehirde çalışıyorsa saygınlığı yok.” (Veli 12, kadin)

"Toplum, ilkokul ögrretmenlerini maaşına göre değerlendiriyor. İlkokulda çok ders var. Eğitime ă̆ırlık verilmiyor. Sadece öğretim yapılıyor. Ufak yaştaki çocuğa bu kadar öğretim dersi olmamall. Vatana, millete fayda ön planda olmalı. Adam okuyor bu sefer hirsızlık, yolsuzluk yapıyor. Vatandaşça bir bilinç oluşmuyor. Eğitim yok artık. İlkokulda iyi bir eğitim verilmiyor artık.” (Veli 7, kadın)

"Toplumda artık öğretmenlere eskisi gibi saygı yok. Önceden öğretmenler karşısında ayă̆a kalkardık. Şimdiki çocuklar ve veliler öğretmene gereğince değer vermiyor. Maaşla alakalı değil 
saygınlı. Son zamanlarda medyanın öğretmeni tanıtımıyla alakall. Öğretmen, öğrencilere kizarsa haberimiz olsun diyor veliler. Öğretmeni sürekli bir şikâyet var. Veli sinirlenince gidip idareye öğretmeni şikâyet ediyor." (Veli 5, erkek)

"Eskiden genel olarak tüm ögrretmenler daha saygındı. Şimdi öğretmenler ayaklar altında. İdare de veliden taraf. Alo 187 şikâyet hattını veliler sıklıkla kullanıyor. Eskiden daha klymetli ve daha önemli bir meslekti. Öğretmenlere performans sistemi geliyor. Artlk veli, ögrenci, müdür öğretmene not verecek. Bu kesinlikle kötü bir uygulama. Liyakat ortadan kalkar. Toplum gözünde ögretmenler yatarak para kazanıyor. Ü̧ ay yaz tatili, on beş tatil. Toplum tarafindan rahat bir meslek olarak gözüküyor. Insanlar evinde bir tane çocuğu zapt edemezken biz öğretmenler 30-35 kişilik sinıflarda çocuklara dersi öğretmeye çalışıyoruz." (Veli 8, kadın)

\section{Sonuç, Tartışma ve Öneriler}

Velilerin sınıf öğretmenlerine olan bakış açılarının incelendiği bu araştırmada, veli görüşleri sonucunda üç adet temaya ulaşılmıştır. Bunlar memnuniyet, özveri ve saygınlık temalarıdır. Memnuniyet temasında görüşme yapılan velilerin yüzde doksanı sınıf öğretmenlerinden memnun olduklarını belirtmişlerdir. Ancak görüşme yapılan iki veli sınıf öğretmenlerinden memnun olmadıklarını belirtmişlerdir. Velilerin sınıf öğretmenlerinden memnuniyet oranının yüzde yüz olması hepimizin istediği bir durumdur. Ancak yüzde onluk bir memnuniyetsizlik durumunun olduğu ortadadır. Veli görüşleri incelendiğinde, velilerin sınıf öğretmenlerinin davranışlarıyla rol model olduklarını özellikle vurgulamışlardır. Sınıf öğretmenlerinin öğrencilere rol model olma durumu ile ilgili olarak benzer bir şekilde, Sünbül (1996) tarafindan yapılan araştırmaya göre; öğretmen davranışlarıyla öğrencilere rol model olan meslek mensubudur. Bu durum ise sınıf öğretmenlerinin sanatkâr gibi davranmasını gerektirmektedir. Öğretmenin değerleri, tutumları, deneyimleri, davranışları; öğrencilerini, toplumu, kendi mesleki geleceğini ve meslektaşlarını etkilemektedir. Çocuklarının eğitimi açısından sınıf öğretmenlerini çok değerli görmektedirler. Ayrıca veliler sınıf öğretmenlerinin kendileriyle ve öğrencilerle ilgilenmesini çok kıymetli olarak değerlendirmektedirler. Bir velinin (Veli 5, erkek) sınıf öğretmeni hakkında dile getirdikleri dikkate değerdir: "İlkokul ögretmeninden memnunum. Ŏglumu kaybetmediği için. Ŏglumla bireysel ilgilenmekte. Oğlumda dikkat eksikliği olduğunu kendisi tespit etti. Ona göre de program oluşturduk." Veli bu düşüncesiyle sınıf öğretmeninin oğlunun gelişimindeki büyük katkısını vurgulamıştır. Bununla birlikte, veliler sınıf öğretmenlerinin kendileriyle iletişim halinde olmalarından büyük memnuniyet duyduklarını dile getirmişlerdir. Bu durumun yanı sıra veli görüşlerine göre, bazı velilerin okula bağış yaparak iyi sınıf öğretmeninin sınıfına çocuklarını aldırma çabalarının olduğu tespit edilmiştir. Oysaki Milli Eğitim Bakanlığ1 Müsteşarlığının 20.07.2011 tarih ve 2011/40 sayılı genelgesinde; Milli Eğitim Bakanlığ1 Temel Eğitim Genel Müdürlüğünün 28.09.2016 tarih ve 10230228-200-E.10388448 sayılı yazısının 25. maddesinde kayıt veya bağış parası alınmayacağı belirtilmiştir.

Veli görüşleri sonucunda ulaşılan bir başka tema özveri temasıdır. Velilerin tamamı sınıf öğretmenlerinin özverili bir şekilde çalıştı̆̆ını belirtmişlerdir. Sınıf öğretmenlerinin canla başla öğrencileri yetiştirmek için görev yaptıklarını dile getirmişleridir. Konu ile ilgili olarak Hayes (2010) öğretmenin sorumluluklarından birinin fedakârlık olduğunu vurgulamıştır. Ortaya çıkan bu durum, kutsal bir meslek olan öğretmenlik mesleğini, ilkokul öğretmenlerinin nasıl canla ve başla yerine getirdiklerini gözler önüne sermektedir. Veliler sınıf öğretmenlerinin büyük bir fedakârlıkla çocuklarıyla ilgilendiklerini özellikle vurgulamışlardır. İlkokul öğretmenlerimizin üstün çalışkanlıkları araştırma sonucunda ortaya çıkmıştır. Katılımcı veli görüşleri sonucunda, sınıf öğretmenlerinin büyük bir özveri ile öğrencileriyle ilgilendikleri tespit edilmiştir. Veliler sınıf öğretmeninin kendi çocuklarıyla ilgilenmelerini daha fazla istemektedirler. Sınıf öğretmeninin öğrencilerle bire bir ilgilenmesi sınıf mevcudu ile doğrudan ilgilidir. Nitekim bir veli (Veli 15, erkek) sınıfin kalabalık olmasını vurgulamaktadır. Sınıf kalabalıklığı ile ilgili olarak Binicioğlu (2010), özellikle ilköğretim sınıflarında kalabalık olan sınıf mevcudu nedeniyle öğretmenlerin öğrencilere yeterince zaman ayıramadığını dile getirmektedir. Sınıf öğretmenlerinin özverili çalışmaları ile ilgili bir velinin görüşleri dikkate değerdir: "Canı çıkıyor zavallı öğretmenin. Çocukla ilgili bir şey olduğunda bizi 
arıyor. Çok ilgili. (Veli 2, kadın)" Veli, sınıf öğretmeninin canla başla çalıştığını özellikle vurgulamaktadır. Bunun yanı sıra bir veli, sınıf öğretmeni için şunları dile getirmiştir: "Eski bir televizyonun içini boşaltmış. Çocuklar her gün televizyonun arkasına geçip haber okuyor. Ögrencilerin özgüvenleri gelişsin diye. (Veli 6, erkek)" Sinıf öğretmeninin bu özverili çalışması velinin çok hoşuna gitmiştir. Ayrıca bir veli, sınıf öğretmeni hakkında; "Dirayetli öğretmen. Oğlumu adam etti. (Veli 17, kadın)" şeklinde görüş bildirmiştir. Öğrencinin gelişimine sınıf öğretmeninin olumlu katkılarını özellikle vurgulamıştır.

Araştırma sonucunda ulaşılan son tema saygınlık temasıdır. Saygınlık teması ile ilgili olarak çok çeşitli veli görüşleri tespit edilmiştir. Bazı veliler, sınıf öğretmenlerini çok saygın kişiler olarak nitelendirmiştir. Kuşkusuz bu saygınlık beklentiler ile ilgilidir. Konu ile ilgili olarak Hayes (2010) toplumun öğretmenlerden büyük beklentiler içerisinde olduğunu belirtmektedir. Bir veli, sınıf öğretmenlerinin maaşlarının düşük olması nedeniyle toplumda hak ettikleri saygıyı göremediklerini belirtmiştir. Bir başka veli ise, sınıf öğretmenlerinin saygınlığının eskisi kadar olmadığını söylemiştir. Ancak bu saygınlık azalmasının sebebini medya ve toplumun bakış açısıyla ilişkilendirmiştir. Bir diğer veli ise, yerleşim yerlerine göre sınıf öğretmenlerine olan saygının değiştiğini vurgulamıştır. Araştırma bulgularıyla ilgili olarak Çelikten, Şanal ve Yeni (2005) ile Baskan (2001) da öğretmen maaşlarının düşüklüğü nedeniyle, öğretmenlere toplum tarafından yeterli saygının gösterilmediğini vurgulamışlardır. Konu ile ilgili olarak bir veli; "Ben daha ilkokul ögretmenimin elini öperim. Nerde görsem. Çünkü benim üzerimde hem insani hem öğretmenlik konusunda büyük bir etki biraktı. Sevdiğim bir insandl. (Veli 1, erkek)" şeklinde görüş bildirmiştir. Velinin ilkokul öğretmenine olan saygısı dikkate değerdir. Ayrıca bir veli; "Maaşla ve kalabalıkla ilgili. Sayılarının çokluğu ve maaşlarının azlı̆̆ı toplumdaki saygınlıklarını bitirdi. (Veli 3, erkek)" şeklinde görüş bildirmiştir. Sınıf öğretmenlerinin sayılarının çok olmasını ve maaşlarının düşük olmasını saygınlıklarının azalmasıyla ilişkilendirmiştir. Bunun yanı sıra bir velinin görüşleri dikkate değerdir; "Toplumda artık öğretmenlere eskisi gibi saygl yok. Önceden öğretmenler karşısında ayă̆a kalkardık. Şimdiki çocuklar ve veliler ögretmene gereğince değer vermiyor. Son zamanlarda medyanın ögretmeni tanıtımıyla alakalı. Öğretmen, öğrencilere kızarsa haberimiz olsun diyor veliler. Öğretmeni sürekli bir şikâyet var. Veli sinirlenince gidip idareye öğretmeni şikâyet ediyor. (Veli 5, erkek)" Veli öğretmenlere eskisi gibi saygı gösterilmediğini belirtmektedir. Medyanın önemini vurgulamıştır. Velilerin sürekli sınıf öğretmenlerini yöneticilere şikâyet ettiklerini dile getirmektedir. Ayrıca konu ile ilgili olarak bir velinin tespitleri önemlidir; "Eskiden genel olarak tüm öğretmenler daha saygındı. Şimdi öğretmenler ayaklar altında. İdare de veliden taraf. Alo 187 şikâyet hattını veliler sıklıkla kullanıyor. Eskiden daha klymetli ve daha önemli bir meslekti. Toplum gözünde ögretmenler yatarak para kazanıyor. Üç ay yaz tatili, on beş tatil. Toplum tarafindan rahat bir meslek olarak gözüküyor. (Veli 8, kadın)" Toplumun öğretmenlere bakış açısını göstermesi açısından önemli bir bulgudur. Veli görüşleri doğrultusunda, sınıf öğretmenlerinin eskisi kadar saygı görmedikleri dikkate değerdir. Bunun yanı sıra, haberlerde ne yazık ki veli tarafından dövülen öğretmenlere rastlamaktayız. Bu içler acısı durum, öğretmenlik mesleğine gösterilen saygınlık ile doğrudan ilişkilidir.

Araştırma sonuçları bağlamında şu önerilerde bulunulmuştur: Öncelikle sınıf öğretmenleri ve daha sonra tüm öğretmenler büyük bir özveri ile görev yapmaktadırlar. Yapılan araştırma sonucunda, saygınlık teması ile ilgili olarak öğretmen maaşlarının artırılması önerilmektedir. Veliler sınıf öğretmeninin öğrencilerle bire bir ilgilenmesini istemektedir. Bu birebir ilgilenme ise kalabalık sınıflarda mümkün olamamaktadır. İlkokullarda sınıf mevcutları 20 kişinin üzerinde olmamalıdır. Veli görüşleri bağlamında, sınıf öğretmenleri ile velilerin iletişimini artırmak amacıyla cep telefonları üzerinden whatsapp grupları kurmaları önerilmektedir. 
Açıklamalar: Bu çalışmanın kısa hâli 08-11 Mayıs 2017 tarihlerinde Lefke Avrupa Üniversitesinde düzenlenen 16. Uluslararası Sınıf Öğretmenliği Eğitimi Sempozyumunda sunulmuştur. 


\section{Kaynaklar}

Aydın, R., Şahin, H. ve Topal, T. (2008). Türkiye'de ilköğretime sınıf öğretmeni yetiştirmede nitelik arayışları, Türkiye Sosyal Araştırmalar Dergisi, 12(2), 119-142.

Aydoğan, İ. (2006). İlköğretim okullarında okul-çevre ilişkilerinin düzeyi. Sosyal Bilimler Araştırmaları Dergisi, 2, 121-136.

Azar, A. (2011). Türkiye'deki öğretmen eğitimi üzerine bir söylem: nitelik mi, nicelik mi? Yükseköğretim ve Bilim Dergisi, 1(1), 36-38.

Baskan, G. A. (2001). Öğretmenlik mesleği ve öğretmen yetiştirmede yeniden yapılanma. Hacettepe Üniversitesi Eğitim Fakültesi Dergisi, 20, 16-25.

Bayrakdar, M. ve Yiğit, B. (2006). Okul-çevre ilişkileri (1. Baskı). Ankara: Pegem A Yayıncılık.

Binicioğlu, G. (2010). İlköğretimde okul-aile iletişim etkinlikleri: öğretmen ve veli görüşleri. Yayımlanmamış Yüksek Lisans Tezi. Anadolu Üniversitesi Eğitim Bilimleri Enstitüsü, Eskișehir.

Christensen, L. B., Johnson, R. B. ve Turner, L. A. (2015). Araştırma yöntemleri desen ve analiz (Çev. Edt: Ahmet Aypay). Ankara: Anı Yayınc1lık.

Creswell, J. W. (2012). Educational research: Planning, conducting, and evaluating quantitative and qualitative research (4th ed.). Boston: Pearson Education, Inc.

Çelenk, S. (2003). Okul başarısının ön koşulu: okul aile dayanışması. İlköğretim-Online, 2(2), 28-34.

Çelikten, M., Şanal, M. ve Yeni, Y. (2005). Öğretmenlik mesleği ve özellikleri. Sosyal Bilimler Enstitüsü Dergisi, 19, 207-237.

Fraenkel, J. R., Wallen, N. E. ve Hyun, H. H. (2011). How to design and evaluate research in education (8th edition). McGraw-Hill. New York.

Genç, S. Z. (2005). İlköğretim 1. kademedeki okul-aile işbirliği ile ilgili öğretmen ve veli görüşleri. Türk Eğitim Bilimleri Dergisi, 3(2), 227-243.

Glesne, C. (2012). Nitel araştırmaya giriş. (A. Ersoy ve P. Yalçınoğlu, Çev.). Ankara: Anı Yayıncılık.

Gliner, J. A., Morgan, G. A. ve Leech, N. L. (2015). Uygulamada araştırma yöntemleri: desen ve analizi bütünleştiren yaklaşım (Çev. Ed.: Selahattin Turan). Ankara: Nobel Yayın Dağıtım.

Hayes, D. (2009). Encyclopedia of primary education. Oxon: Routledge.

Kavcar, C. (1980). Nitelikli öğretmen sorunu. Eğitim ve Bilim, 5(28). 17-22.

Megay-Nespoli, K. (2005). Essential characteristics of elementary level teachers. Encyclopedia Of Education And Human Development (Stephen J. Farenga and Daniel Ness, editors). New York: M.E. Sharpe, Inc.

Merriam, S. B. (2013). Nitel araştırma desen ve uygulama için bir rehber (Çev. Ed.: Selahattin Turan). Ankara: Nobel Akademik Yayıncılık.

Miles, M. B. ve Huberman, A. M. (2015). Nitel veri analizi (Çev. Ed Sadegül Akbaba Altun ve Ali Ersoy). Ankara: Pegem Akademi

Mustan, T. (2002). Dünyada ve Türkiyede öğretmen yetiştirmede yeni yaklaşımlar. Kuram ve Uygulamada Eğitim Yönetimi Dergisi, 8(1), 115-127.

Paredes, V. (2014). A teacher like me or a student like me? Role model versus teacher bias effect. Economics of Education Review, 39, 38-49.

Patton, M. Q. (2014). Nitel araştırma ve değerlendirme yöntemleri (3. Baskıdan Çeviri) (Çev. Edt: Mesut Bütün, Selçuk Beşir Demir). Ankara: Pegem Akademi.

Shein, P. ve Chiou, W. (2011). Teachers as role models for students' learning styles. Social Behavior and Personality: An International Journal, 39, 1097-1104. DOI: https://doi.org/10.2224/sbp.2011.39.8.1097.

Sünbül, A. M. (1996). Öğretmen niteliği ve öğretimdeki rolleri. Kuram ve Uygulamada Eğitim Yönetimi Dergisi, 2(4), 597-608. 
Şimşek, H. ve Tanaydın, D. (2002). İlköğretimde veli katılımı: Öğretmen-veli-psikolojik danışman üçgeni. Illkögretim-Online, 1(1), 12-16.

Waid, K. B. ve McNergney, R. F. (2002). Teacher Encyclopedia of Education. USA: Macmillian Reference.

Wall, K. ve Hall, E. (2016). Teachers as metacognitive role models. European Journal of Teacher Education, 39(4), 403-418.

Yıldırım, A. ve Şimşek, H. (2006). Sosyal bilimlerde nitel araştırma yöntemleri (6. Baskı). Ankara: Seçkin Yayıncılık. 


\section{Introduction}

\section{Extended Abstract}

There are three important factors in the school's success. These; teacher, student and parent. Parents, who are one of these legs, are very important in the perspective of the teacher and the school. Parents also reflects on the child's view of the classroom teacher. In addition, the opinions of the parents about the class teachers give us insight into the point of view of the society class teachers. Because of this importance, it is important to examine the views of the parents on their class teachers. Classroom teachers are working in the primary school, which is the first stage of 12 years compulsory education in our country. The primary school word is composed of a combination of the words "first" and "school". Primary school comes from French "école primaire". It means that students are the first stage in compulsory education.

\section{Method}

The research was carried out by means of phenomenology from qualitative research methods. The case focuses on phenomena in which we are aware of science, but we do not have an in-depth and detailed understanding. In the identification of the participants, easy accessible case sampling and criterion sampling were used for purposeful sampling methods. The readily available case sampling method gives speed and practicality to research. Criteria sampling method is also used. The semistructured interview form approach includes a list of questions or topics to be discussed during the interview. The semi-structured interview format helps to open the subject with different questions during the course of the speech, to come up with a variety of new ideas and to reach new ideas about the subject. In order to form a semi-structured interview form, the literature on the topic was first examined. The semi-structured interview form consists of two parts. In the first part, questions were asked to determine the demographic characteristics of classroom teachers. In the second part, the parents were asked about their opinions about class teachers.

\section{Result}

The first theme reached as a result of parental perspectives is satisfaction. A great deal of the interviewed parents stated that they were satisfied with their teachers. However, the two parents have expressed their dissatisfaction with the classroom teacher. The second theme is self-sacrifice. In the theme of self-sacrifice, the opinions of the parents about their self-sacrificing studies of the class teachers are stated. The last theme that comes to us is respectability. In respect of dignity, the views of the parents on the respectability of the classroom teacher are mentioned.

\section{Discussion and Conlusion}

In this research, in which the society's point of view towards classroom teachers was examined, three themes were reached as a result of parental interviews. These are the themes of satisfaction, selfsacrifice and respect. A great majority of the parents who were interviewed on satisfaction basis stated that they were satisfied with their class teachers. However, the two interviewees stated that they were not satisfied with their classroom teachers. According to parents' opinion, it is determined that some parents try to donate their children to the class of the good classroom teacher by donating to the school. However, in the general no. 2011/40 dated 20.07.2011 of the Undersecretariat of the Ministry of National Education and in article 25 of the Ministry of National Education General Directorate of Basic Education dated 28.09.2016 and numbered 10230228-200-E.10388448; it has been stated that the registration or donation money will not be taken.

Another theme reached as a result of parental views is the theme of self-sacrifice. All of the parents stated that class teachers work in a self-sacrificing manner. They have stated that class teachers are working to train beginners. The last theme reached as a result of research is respectability. A wide variety of parental opinions have been identified in relation to respectability. Some parents and wives have called class teachers very respected. A parent has stated that class teachers do not see the respect 
they deserve in society because of their low salaries. Another parent said that it was not as old as the reputation of class teachers. However, this has linked the reason for the declining reputation with the viewpoint of media and society. Another parent emphasized that the respect for class teachers has changed according to the settlements.

In the context of the research results, the following suggestions were made: The media should stop making humiliating news from teachers. When society sees the teacher in a wrong behavior in the news, he immediately goes to generalize and starts to see all the teachers in the same way. First of all the class teachers and then all the teachers are working with great devotion. As a result of the research, it is suggested that teacher salaries should be increased in relation to respectability. The welle wants the class teacher to take care of the pupils individually. It is not possible to take care of this individual in crowded classrooms. Classrooms in primary school should not exceed 20 people. 
Ek-1: Yarı Yapılandırılmış Görüşme Formu

YARI YAPILANDIRILMIŞ GÖRÜŞME FORMU

\section{Veli Demografik Özellikleri}

Veli yaşı:

Veli cinsiyeti:

Çocuğun ilkokul kaçıncı sınıfa gittiği:

Veli mesleği:

\section{Görüşme Soruları}

1.Çocuğunuzun ilkokul öğretmeninden memnun musunuz? Açıklar mısınız?

2.Çocuğunuzun ilkokul öğretmeninin en sevdiğiniz uygulamaları nelerdir?

3.Çocuğunuzun ilkokul öğretmeninin hoşunuza gitmeyen uygulamaları var mıdır? Varsa bunlar nelerdir?

4.Kendi çocukluğunuzdaki ilkokul öğretmeniniz ile çocuğunuzun ilkokul öğretmenini kıyaslar misiniz?

5.Günümüzdeki ilkokul öğretmenleri hakkında neler düşünüyorsunuz?

6.İlkokul öğretmenlerinin gerek sizinle olan iletişimi gerekse çocuğunuzun eğitimine yönelik önerileriniz nelerdir? 